\title{
INVESTIGATION OF THE EFFECTIVENESS OF MOTHER ENZYME ON MODEL ORGANIC WASTE MATERIAL BY ENZYME DEGRADATION
}

\author{
A.G. I. I. Wimaladharma', N. J. G. J. Bandara' \& A.H.D.O. Bammunuarachchi2 \\ 1. Department of Forestry and Environmental Science, \\ University of Sri jayewardenepura \\ 2 Department of Chemistry \\ University of Sri Jayewardenepura
}

Continuous disposal of solid waste and their collection creates a severe environmental and health hazard. In Sri Lanka the major perceitage of municipal solid waste is organic wastc. Hence, one-way of over coming this problem is to increase the rate degradation of organic material in which enzyme and microorganisms play a big role. Mother Enzyme (ME) is said to be one such mixture of enzymes and nicroorganisms.

Objectives of this research was to identify the constituents of the ME, to determine the effectiveness of the ME on degradation of different types of organic wastes, and to determine the effective levels of ME for different types of organic wastes.

Macconkey agar, Nutrient agar and Sabouraud Dextrose Agar were used to find the total number and the types of microorganisms present in the ME. Effect of Mother enzyme on different of organic waste were done by using Farm (cattle and poultry) waste, kitchen wastes and fruit industry wastes in the presence and in the absence of ME with replication. Weight reduction with time was noted down. To estimate the effect of ME on model organic waste, wheat flour, egg yolk and coconut oil were used. Alanine, Glucose and Acid value estimation were done to estimate the ratc of degradation of the macromolecules in the presence of and in the absence of ME. In order to find out the effective levels of ME farm (cattle and poultry), kitchen wastes and fruit industry wastes were used with replication. $2 \mathrm{~g} / \mathrm{lkg}$ and $0.5 \mathrm{~g} / \mathrm{kg}$ of mother enzyme was introduced and weight reduction was noted down.

Form the Microbiological analysis, Staphylococcus aureus, Esscherichia colli, and Mucor, were found to be present in ME and the total number of organisms present was $13 \times 10^{-14}$.

From the study it was revealed that the break down of model organic matter - fats and proteins occur quite fast in the presence of nother enzyme. But mother enzyme does not significantly increase breaking down of carbohydrates.

Increased or decreased levels of ME have no significant effect on mixed organic wastes. Due to our consumption pattern most of organic wastes generated in Sri Lanka are of carbohydrate origin. This may be the reason why there is no significant effect due to ME on mixtures of organic wastes found in Sri Lanka

\footnotetext{
Proceedings of the Eighth Anmual Forestry and Environment Symposium 2002 of the Department of
} Forestry and Environmental Science, University of Sri Jayewardenepura, Sri Lanka 